\title{
URBAN-RURAL DISPARITY: THE UTILIZATION OF PRIMARY HEALTHCARE CENTERS AMONG ELDERLY IN EAST JAVA, INDONESIA
}

\author{
Disparitas Perkotaan-Perdesaan: Pemanfaatan Puskesmas oleh Lansia \\ di Jawa Timur, Indonesia
}

*Ratna Dwi Wulandari', Agung Dwi Laksono²

${ }^{1}$ Faculty of Public Health, Universitas Airlangga, Indonesia

${ }^{2}$ National Institute of Health Research and Development, Ministry of Health, Indonesia

${ }^{*}$ Correspondence: ratna-d-w@fkm.unair.ac.id

\begin{abstract}
Background: Urban always attracts investors to invest. Health facilities in urban areas are growing rapidly compared to villages. This condition is estimated to contribute to the disparity of urban-rural areas in the utilization of health services. Studying the utilization of health services is a way to evaluate the performance of the health care system through its output.

Aim: This study analyzed the urban-rural disparity in the utilization of primary healthcare center by the elderly.

Method: This study used in the 2013 Basic Health Research raw data. The 2013 Basic Health Research was designed as a cross-sectional survey. With the multi-stage cluster random sampling method, 25,813 elderly people in East Java Province participated. Data were analyzed using Multinomial Logistic Regression tests.

Results: Elderly people in urban areas have a better probability of outpatient use of 1.208 than those living in rural areas (OR 1.208; 95\% Cl 1.057-1.380). The elderly who have a primary school and under education have the possibility of 1.558 times more utilizing outpatients in primary healthcare centers than the elderly who have college education levels (OR 1.558; 95\% $\mathrm{Cl} 1.001-2.424$ ).

Conclusion: There was a disparity between urban and rural areas in the utilization of outpatient primary healthcare centers in East Java by the elderly. Policymakers in East Java are recommended to improve facilities and infrastructure of the primary healthcare centers in rural areas by paying attention to the results of this study.
\end{abstract}

Keywords: elderly, urban-rural disparities, primary healthcare center, healthcare utilization, inpatient-outpatient.

\begin{abstract}
ABSTRAK
Pendahuluan: Perkotaan selalu lebih menarik investor untuk berinvestasi. Fasilitas kesehatan di perkotaan berkembang pesat dibanding desa. Kondisi ini diperkirakan turut mendorong terjadinya disparitas perkotaanperdesaan dalam pemanfaatan pelayanan kesehatan. Mempelajari pemanfaatan layanan kesehatan adalah cara untuk mengevaluasi kinerja sistem perawatan kesehatan melalui output-nya.

Tujuan: Penelitian ini dimaksudkan untuk menganalisis disparitas perkotaan-perdesaan dalam pemanfaatan Puskesmas oleh lansia.

Metode: Penelitian ini menggunakan data mentah Riset Kesehatan Dasar (Riskesdas) tahun 2013. Riskesdas dirancang sebagai survei cross-sectional. Dengan metode multi-stage cluster random sampling didapatkan 25.813 lansia. Data dianalisis menggunakan uji Regresi Logistik Multinomial.

Hasil: Lansia di daerah perkotaan memiliki kemungkinan yang lebih baik untuk penggunaan rawat jalan 1.208 kali daripada mereka yang tinggal di daerah perdesaan (OR 1,208; 95\% Cl 1,057-1,380). Lansia dengan Pendidikan SD ke bawah memiliki kemungkinan 1.558 kali lebih banyak memanfaatkan rawat jalan di Puskesmas daripada lansia dengan pendidikan perguruan tinggi (OR 1,558; 95\% Cl 1,001-2,424).

Kesimpulan: Ada disparitas antara daerah perkotaan dan perdesaan dalam pemanfaatan Puskesmas di Jawa Timur oleh lansia dalam kategori rawat jalan. Pembuat kebijakan di Jawa Timur direkomendasikan untuk memperbaiki sarana dan prasarana Puskesmas di wilayah perdesaan dengan memperhatikan poin hasil penelitian ini.
\end{abstract}

Kata kunci: lansia, disparitas perkotaan-perdesaan, puskesmas, pemanfaatan pelayanan kesehatan, rawat jalan-rawat inap.

Received: 15 January 2019 Accepted: 5 March 2019 Published: 24 May 2019 


\section{INTRODUCTION}

A primary healthcare center (Puskesmas) is a technically implemented unit of a health office to carry out health development in a district/city level. Primary healthcare centers has a strategic role in communities as an entrance before they get to be referred to advanced health services like a hospital (Tebay, 2018; Hamzah and Tamba, 2018). Primary healthcare center provides outpatient and inpatient emergency services. Inpatient services in primary healthcare center are often provided due to inaccessible hospitals (Sari et al., 2018).

The World Health Organization (WHO) is responsible for public health worldwide by being aware of the elderly as one of the vulnerable groups apart from children, pregnant women, malnourished people, and sick people (World Health Organization, 2018). East Java is one of the provinces with a significant increase in the elderly population, $10.35 \%$ in 2010 to $13.09 \%$ in 2019 (East Java Central Bureau, 2019). This condition has made the East Java provincial government make geriatrics one of the priority programs by realizing Elderly Friendly Health Centers (East Java Provincial Health Office, 2018).

Studying the utilization of health services is a way to evaluate the performance of the health care system as its output. Other outputs that can assess the performance of the health care system are equity (Brydsten, Hammarström, and San Sebastian, 2018; Dehbarez et al., 2018), acceptability (Laksono and Rachmawaty, 2013), accessibility (Song et al., 2018; Mubasyiroh, Nurhotimah, and Laksono, 2016), effectiveness (Rinaldi, Kiadaliri, and HaghparastBidgoli, 2018), and efficiency (Yildiz, Heboyan, and Khan, 2018).

The disparity of health services between urban and rural areas is always interesting to study because many things can be found in this case. One of the different characteristics of urban and rural areas is accelerating development. Urban areas tend to develop faster than rural ones do especially in the health sector. Investors are more interested in investing health facilities in urban areas because they grow rapidly with a variety of more modern medical equipment. The density of occupancy makes health development concentrated in urban areas. If it is not controlled properly, it will cause huge inequality between urban and rural. This case must be scrutinized to give an idea about imbalanced access of rural-urban communities' rights (Holliday et al., 2017; Yu, Matthes, and Wei, 2018; Li et al., 2018). In fact, according to the principle of right equality, there should not be a difference in the fulfillment of right to health wherever the communities settle. Research examining the disparity can be a consideration for the government to improve health facilities in rural areas. The government must be responsible for minimizing the disparity (Fu et al., 2018; Karuaihe and Wandschneider, 2018; Wong and Szeto, 2018; Li, Yao, and Yin, 2018; Song et al., 2018).

Based on this issue, this study was aimed to analyze the urban-rural disparity in the use of primary
Doi: 10.20473/jaki.v7i2.2019.147-154

healthcare centers by elderly in East Java Province, Indonesia. By looking further at the disparity in the performance of healthcare system as an output, it can be deliberation for policymakers to make better policies of healthcare system (Megatsari et al., 2018), as well as budgeting policies to strengthen less paramount outputs (Pratiwi et al., 2014).

\section{METHOD}

This research involved elderly aged 50 years and over (Laksono, Nantabah, and Wulandari, 2018; Wulandari et al., 2019). The raw data used in this study came from Basic Health Research or Riset Kesehatan Dasar (Riskesdas) in 2013. The population in this study were elderly throughout East Java. With multi-stage cluster random sampling, as many as 25,813 elderly respondents in East Java Province were involved (National Institute of Health Research and Development, 2013).

Based on the operational definition, utilization of primary healthcare centers meant that elderly used outpatient and inpatient services in primary healthcare centers. The data included the utilization of last-month outpatient services and last-year inpatient services by the elderly. From this limitation, it was assumed that the elderly could still remember every outpatient and inpatient situation well. The variable in this research included insurance ownership as the respondent's acknowledgment of insurance ownership, such as no insurance, public insurance (Health Insurance or Asuransi Kesehatan (Askes), District Government Free Care Scheme or Jaminan Kesehatan Masyarakat (Jamkesmas), Local Government Free Care Scheme or Jaminan Kesehatan Daerah (Jamkesda), Social Security for Workers or Jaminan Sosial Tenaga Kerja (Jamsostek)), and private insurance. Socioeconomic status is an index of the quintile for goods ownership stated by the respondents (National Institute of Health Research and Development, 2013).

The t-test was used to test the age variable in the other variable categories while Chi-Square was used to examine 9 (nine) dichotomous variables, such as the utilization of primary healthcare centers, gender, marital status, education, employment, socioeconomic condition, insurance, travel time, and transportation cost to primary healthcare centers. This statistical test was used to find whether the use of primary healthcare centersin the urban and rural areas by the elderly was significantly different or not. Besides, the multinomial logistic regression was used to study the disparity of hospital use by the elderly in rural and urban areas, as well as to assess the significance level (Xu et al., 2018).

\section{RESULTS AND DISCUSSION}

Figure 1 and 2 describe the utilization of primary healthcare centers based on area and socioeconomic status. The picture shows similar characteristics. Middle-class elderly dominated to use outpatient health services in urban areas while elderly with high 
socioeconomic status utilized more outpatient health services in rural areas. The same results were found in the use of inpatient health services in both areas.

Table 1 shows that there is a disparity in the utilization of primary healthcare centers in urban and rural areas. The disparity was significantly different. Based on Table 1, the elderly in rural areas had a slightly older age than average (61.91 years). Based on gender, both regions were dominated by females. Even though the proportion was almost balanced, the gender variable was not significantly different. Table 1 shows that both urban and rural areas were dominated by married elderly $(74.1 \%)$. Whereas $0.9 \%$ elderly in both areas were unmarried. Table 1 also shows that East Java was dominated by the elderly who had low education like primary school and under. There were $93 \%$ elderly and $68 \%$ elderly who had low education in rural areas and urban areas respectively.

Based on employment, urban areas were dominated by the unemployed elderly. In contrast, the elderly in rural areas of East Java worked as farmers, fishermen, or labors. It was found that employement also contributes to the utilization of primary healthcare centers by elderly. In terms of socioeconomic characteristics, most of the elderly in urban areas came from high socioeconomic levels (Quintile 4 and 5 at $50.6 \%$ ). Meanwhile, most of the elderly in rural areas had low socioeconomic status (Quintile 1 and 2 at $58.7 \%$ )

Table 1 shows that in both areas, most of the elderly did not have insurance. For those who have insurance, the insurance was public insurance managed by the government. In addition the elderly in urban areas spent shorter time to primary healthcare centers than those in rural areas., Meanwhile, $60.3 \%$ elderly in rural areas spent more than IDR 5,000 . Insurance, distance, and transportation cost significantly influence the utilization of primary healthcare centers by elderly.

The results of multinomial logistic regression can be seen in Table 2. This test was conducted to detect disparity in the utilization of primary healthcare centers among elderly in urban and rural areas of East Java. Table 2 shows that the disparity in the utilization of primary healthcare centers was found in outpatient health services. The elderly in urban areas had better potential to use of outpatient healthservices than those in rural areas (OR 1.208; 95\% Cl 1.057-1.380). Meanwhile, the elderly in rural areas preferable using inpatient health services. Disparity in the utilization of inpatient and outpatient health services is not statistically significant towards both areas.

The findings in this study indicate that there was no significant difference in the utilization of inpatient health services among the elderly in rural areas and urban areas. As a result, the level of utilization of the inpatient health services by the elderly in both areas was relatively the same. The findings show that the conditions where the elderly utilized inpatient health services were non-negotiable. In terms of accessibility, the elderly in rural areas had worse access than those in urban ones. However, if they need more advanced
Doi: 10.20473/jaki.v7i2.2019.147-154

treatment and hospitalization, they will be referred to hospital. This distinguishes the use of outpatient health services in rural areas and urban areas. The elderly rarely used outpatient health services because of the remote location. Even though the elderly had complaints, they will not go to primary healthcare centers. As a result, their disease tends to be severe and directly requires inpatient health treatment (Gonzales 2005; Lungu et al., 2018).

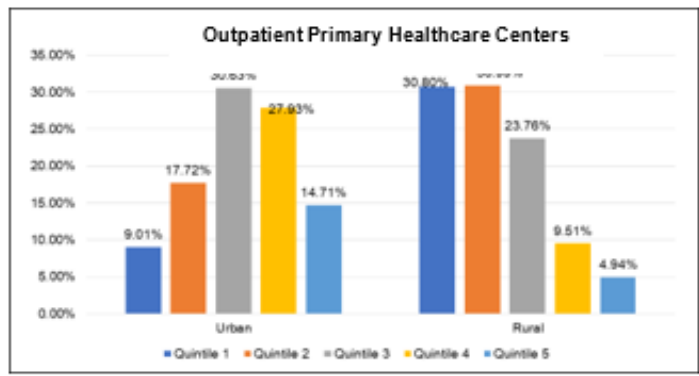

Figure 1. The Utilization of Outpatient Health

Services in Primary Healthcare Centers among

Elderly in East Java Based on Areas (Urban-Rural) and Socioeconomic Status.

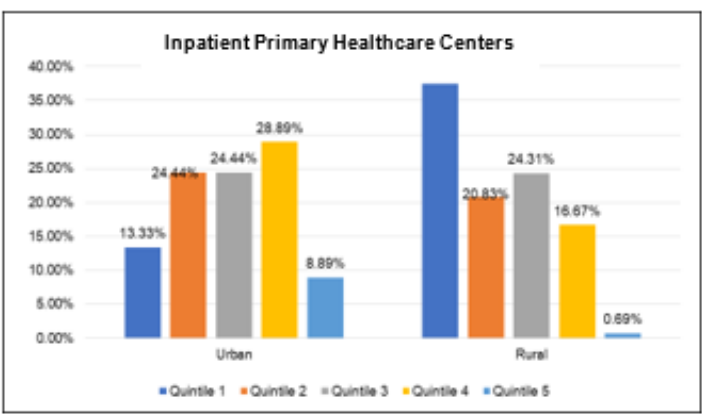

Figure 2. The Utilization of Inpatient Health Services in Primary Healthcare Centers among Elderly in

East Java Based on Areas (Urban-Rural) and Socioeconomic Status.

Table 2 shows that age variable influences the utilization of primary healthcare centers. It shows that the education level also influences the utilization of outpatient health services. The elderly who did not graduate from primary school and under had more possibility of 1.558 times in utilizing outpatient health services in primary healthcare centers than the elderly who graduated from college (OR 1.558; 95\% Cl 1.0012.424). The older, the more unavoidable those suffering from the disease. This condition allows them to utilize higher health facilities (Chiapella, Menna, and Mamprin, 2018).

The elderly with a lower level of education utilize more outpatient health services, and the possibility of elderly morbidity based on education was higher. The higher level of morbidity can be caused by the elderly's unhealthy lifestyle and low level of education. The ability to promote preventive action is lower so that their physical condition becomes more vulnerable. Elderly with higher education have better ability to absorb information about health so they have a better healthy 
lifestyle (Hahn, Truman, and Williams, 2018; Kusumawardani et al., 2018).

The elderly can be considered as vulnerable groups. Because of their vulnerability, the elderlies are relatively more difficult to mobile. Data show that many elderlies had degenerative diseases. These further limit their movement. Besides, many elderly live together as
Doi: 10.20473/jaki.v7i2.2019.147-154

a couple because their children already have their own house, even live in other cities. By that, elderly health is unnoticed unless the elderly are truly ill that results in serious consequences. The results of this study can be considered to improve health programs targeting the elderly (Putri and Riasminis, 2013; Fu et al., 2018).

Table 1. Statistic Description of Utilization of Primary Healthcare Centers by Elderly in East Java-Indonesia based on the 2013 Basic Health Research.

\begin{tabular}{|c|c|c|c|c|}
\hline \multirow{2}{*}{ Characteristics } & \multicolumn{2}{|c|}{ Areas } & \multirow{2}{*}{ All } & \multirow{2}{*}{$\mathbf{P}$} \\
\hline & Urban & Rural & & \\
\hline Utilization of Primary health care centers & & & & 0.000 \\
\hline - Outpatient & $666(5.1 \%)$ & $526(4,1 \%)$ & $1,192(4.6 \%)$ & \\
\hline - Inpatient & $90(0.7 \%)$ & $144(1.1 \%)$ & $234(0.9 \%)$ & \\
\hline - No utilization & $12,326(94.2 \%)$ & $12,061(94.7 \%)$ & $24,387(94.5 \%)$ & \\
\hline Age (mean) & $13,082(61.12)$ & $12,731(61.91)$ & $25,813(61.51)$ & 0,000 \\
\hline Gender & & & & 0.934 \\
\hline - Male & $6,169(47.2 \%)$ & $6,010(47.2 \%)$ & $12,719(47.2 \%)$ & \\
\hline - Female (Ref.) & $6,913(52.8 \%)$ & $6,721(52.8 \%)$ & $13,634(52.8 \%)$ & \\
\hline Marital status & & & & 0.000 \\
\hline - Never married & $143(1.1 \%)$ & $86(0.75 \%)$ & $229(0.9 \%)$ & \\
\hline - Married & $9,615(73.5 \%)$ & $9,513(74.7 \%)$ & $19,128(74.1 \%)$ & \\
\hline - Divorce (Ref.) & $3,324(25.4 \%)$ & $3,132(24.6 \%)$ & $6,456(25.0 \%)$ & \\
\hline Education level & & & & 0.000 \\
\hline - Primary school and under & $8,901(68.0 \%)$ & $11,842(93.0 \%)$ & $20,743(80.4 \%)$ & \\
\hline - Junior high school & $1,438(11.0 \%)$ & $463(3.6 \%)$ & $1,901(7.4 \%)$ & \\
\hline - Senior high school & $1,846(14.1 \%)$ & $262(2.1 \%)$ & $2,108(8.2 \%)$ & \\
\hline - College (Ref.) & 897 (96.9\%) & $164(1.3 \%)$ & $1,061(4.1 \%)$ & \\
\hline Work type & & & & 0.000 \\
\hline - No work & $5,458(41.7 \%)$ & $3,919(30.8 \%)$ & $9,377(36.3 \%)$ & \\
\hline - Gov. Employee & $594(4.5 \%)$ & $153(1.2 \%)$ & 747 (2.9\%) & \\
\hline - Employee & $803(6.1 \%)$ & $219(1.7 \%)$ & $1,022(4.0 \%)$ & \\
\hline - Entrepreneur & $2,510(19.2 \%)$ & $1,069(8.4 \%)$ & $3,579(13.9 \%)$ & \\
\hline - Farmer/Fisherman/Labor & $3,158(24.1 \%)$ & $7,074(55.6 \%)$ & $10,232(39.6 \%)$ & \\
\hline - Others (Ref.) & $559(4.3 \%)$ & $297(2.3 \%)$ & 856 3.3\%) & \\
\hline Socioeconomic status & & & & 0.000 \\
\hline - Quintile 1 & $1,085(8.3 \%)$ & $3,799(29.8 \%)$ & $4,883(18.9 \%)$ & \\
\hline - Quintile 2 & $1,944(14.9 \%)$ & $3,678(28.9 \%)$ & $5,622(21.8 \%)$ & \\
\hline - Quintile 3 & $3,438(26.3 \%)$ & $2,927(23.0 \%)$ & 6,365 (24.7\%) & \\
\hline - Quintile 4 & $3,753(28.7 \%)$ & $1,613(12.7 \%)$ & $5,366(20.8 \%)$ & \\
\hline - Quintile 5 (Ref.) & $2,862(21.9 \%)$ & $714(5.6 \%)$ & $3,576(13.9 \%)$ & \\
\hline Insurance & & & & 0.000 \\
\hline - No insurance & $6,809(52.0 \%)$ & $7,509(59.0 \%)$ & $14,318(55.5 \%)$ & \\
\hline - Government-run Insurance & $5,946(45.5 \%)$ & $5,197(40.8 \%)$ & $11,143(43.2 \%)$ & \\
\hline - Private-run Insurance (Ref.) & $327(2.5 \%)$ & $25(0.2 \%)$ & $352(1.4 \%)$ & \\
\hline Travel time & & & & 0.000 \\
\hline - $\leq 10$ Minutes & 6,685 (51.1\%) & $3,311(26,0 \%)$ & 9,996 (38.7\%) & \\
\hline • > 10 Minutes (Ref.) & $6,397(48.9 \%)$ & $9,420(74.0 \%)$ & $15,817(61.3 \%)$ & \\
\hline Transportation Cost & & & & 0.000 \\
\hline$\bullet \leq \operatorname{IDR} 5,000$ & $6,435(49.2 \%)$ & $5,050(39.7 \%)$ & 11,485 (44.5\%) & \\
\hline • > IDR 5,000 (Ref.) & $6,647(50.8 \%)$ & $7,681(60.3 \%)$ & $14,328(55.5 \%)$ & \\
\hline
\end{tabular}


Based on the information in Table 2, socioeconomic status also has a significant influence in utilization of primary healthcare centers by the elderly. The elderly with the socioeconomic level of quintile 1 (the poorest) were likely to use outpatient health services 1.342 times more than those with the quintile 5 (the richest) (OR 1.342; 95\% Cl 1.209-1.750). Meanwhile, in terms of the use of inpatient services, the elderly with the socioeconomic level of quintile 1 had 3.153 more beneficiaries than those who were in the quintile 5 . The elderly in the quintile 1 (very poor) utilizesoutpatient health services higher than the quintile above. Likewise for the use of outpatient services, some references found a correlation between the level of socioeconomics and healthy lifestyle. Economic limitations make people trapped in unhealthy situations and behavior, such as unhealthy housing and unbalanced eating patterns (Yuan et al., 2018; Telleen
Doi: 10.20473/jaki.v7i2.2019.147-154

et al., 2012; Dhruve, Badgaiyan, and Pandey, 2016; Kusumawardani et al., 2018). Table 2 shows that insurance ownership also influences the use of outpatient and inpatient services in primary healthcare centers. The elderly who had public insurance managed by the government had more possibility of 2.349 times in utilizing outpatient health services in primary healthcare centers than those who owned private insurance. Meanwhile, in terms of utilization of inpatient health services, the elderly with public insurance were likely to use $1,603,864$.592 times more than the elderly with private insurance (OR $1,603,864.592 ; 95 \%$ Cl 1,603,864.592-1,603,864.592). The study on the effect of insurance usage have often been conducted. The results of the study showed a positive correlation (El-Sayed, Vail, and Kruk, 2018; Johar et al., 2018; Lee et al., 2018).

Table 2. Multinomial Logistic Regression for The Utilization of Primary Healthcare Centers Among Elderly in East Java-Indonesia based on The 2013 Basic Health Research.

\begin{tabular}{|c|c|c|c|c|c|c|}
\hline \multirow{2}{*}{ Utilization (a) } & \multicolumn{3}{|c|}{ Outpatient $(95 \% \mathrm{Cl})$} & \multicolumn{3}{|c|}{ Inpatient $(95 \% \mathrm{Cl})$} \\
\hline & OR & $\begin{array}{l}\text { Upper } \\
\text { Bound } \\
\end{array}$ & $\begin{array}{l}\text { Lower } \\
\text { Bound }\end{array}$ & OR & Upper Bound & Lower Bound \\
\hline Area: Urban & $1.208^{*}$ & 1.057 & 1.380 & 0.745 & 0.554 & 1.002 \\
\hline Age & 0.996 & 0.989 & 1.003 & $1.023^{*}$ & 1.008 & 1.037 \\
\hline Marital Status: never married & 0.631 & 0.293 & 1.359 & $4.75 \mathrm{E}-007$ & 0.000 & (b) \\
\hline Marital Status: married & 0.982 & 0.852 & 1.133 & 1.329 & 0.960 & 1.838 \\
\hline Edu: primary school \& under & $1.558^{*}$ & 1.001 & 2.424 & 1.004 & 0.324 & 3.115 \\
\hline Edu: junior high school & 1.330 & 0.830 & 2.132 & 0.499 & 0.136 & 1.823 \\
\hline Edu: senior high school & 0.860 & 0.537 & 1.376 & 0.349 & 0.088 & 1.390 \\
\hline Work: No work & 1.095 & 0.796 & 1.505 & 1.215 & 0.526 & 2.808 \\
\hline Work: Gov. Employee & 0.649 & 0.357 & 1.180 & 0.312 & 0.032 & 3.066 \\
\hline Work: Employee & 0.697 & 0.438 & 1.110 & 1.430 & 0.475 & 4.304 \\
\hline Work: Entrepreneur & 0.882 & 0.625 & 1.244 & 1.326 & 0.545 & 3.225 \\
\hline Work: Farmer/Fisherman /Labor & 0.770 & 0.558 & 1.063 & 1.109 & 0.482 & 2.551 \\
\hline Socioeconomic: quintile 1 & $1.342^{*}$ & 1.029 & 1.750 & $3.153^{*}$ & 1.465 & 6.784 \\
\hline Socioeconomic: quintile 2 & $1.380^{*}$ & 1.074 & 1.772 & $2.240^{*}$ & 1.042 & 4.818 \\
\hline Socioeconomic: quintile 3 & $1.370^{*}$ & 1.082 & 1.735 & $2.422^{*}$ & 1.146 & 5.115 \\
\hline Socioeconomic: quintile 4 & 1.166 & 0.922 & 1.475 & $3.001^{*}$ & 1.436 & 6.271 \\
\hline Insurance: Not insured & 1.192 & 0.553 & 2.569 & $1,162,693.851^{*}$ & $895,002.375$ & $1,510,450.731$ \\
\hline Insurance: Government-run & $2.349^{*}$ & 1.093 & 5.052 & $1,603,864.592^{*}$ & $1,603,864.592$ & $1,603,864.592$ \\
\hline Travel time: $\leq 10$ minutes & $1.296^{*}$ & 1.141 & 1.473 & 1.152 & 0.859 & 1.544 \\
\hline Transport. Cost: $\leq$ IDR 5,000 & $1.457^{*}$ & 1.290 & 1.646 & 0.971 & 0.740 & 1.273 \\
\hline
\end{tabular}

Note: (a) The reference category was "no utilization"; (b) Floating point overflow occurred while computing this statistic. Its value is therefore set to system missing; ${ }^{\star}$ Significant at level $95 \%$.

Travelling time and transportation cost also had a significantly effect on the utilization of outpatient health services in public healthcare centers. The elderly who spent $\leq 10$ minutes to public healthcare centers had probability of 1.296 times better to use outpatient health services than those who spent $>10$ minutes (OR 1.296; 95\% Cl 1.141-1.473). Regarding the transportation cost, the elderly who paid less than or equal to IDR 5,000 were likely to use outpatient health services 1.457 times than the elderly who spent more than IDR 5,000 (OR 1.457; 95\% Cl 1.290-1.646). The accessibility of health facilities for elderly in urban areas is better. The distance to health facilities in urban areas is closer, and the length of travel is quicker. Also, the transportation access is easier. This condition causes the barrier for elderly to go to health facilities. 
Meanwhile, some barriers for the elderly in rural areas include longer distance, long time, and more difficult transportation. The more barriers they face, the longer they tend to delay treatment. Thus, they are unable to hold back anymore (Carrillo et al., 2011; Chuah et al., 2018; Laksono, Nantabah, and Wulandari, 2018).

According to studies on health-seeking behavior, it was also found that there was a different pattern of treatment seeking in urban and rural communities. Aside from the access, the socio-cultural differences in urban and rural communities also influence public responses towards the complaints emerging in urban and rural communities. The accessible health facilities and fast flow of information in urban areas tend to make people easily come to health facilities. If there were a few complaints, urban community will immediately seek for treatment in health facilities. Unlike poeple in cities, elderly in rural areas are constrained by access, such as geographical access, length of travel, and transportation (Suharmiati, Laksono and Astuti, 2013; Langley, Wootton, and Grieve, 2018; Song, Shin, and Kim, 2018).

\section{CONCLUSION}

Based on the results of this study, it can be concluded that there is a disparity in the use of outpatient health services in public healthcare centers by elderly who lived both urban and rural areas of East Java. The elderly who lived in urban areas were likely to use more than those who lived in rural areas. The disparity in the utilization of public healthcare centers by the elderly was also influenced by education level, socioeconomic level, insurance ownership, length of travel, and transportation cost. To reduce or minimize the disparity in the utilization of public healthcare centers by the elderly in East Java, policymakers can use the findings as a cornerstone on the equality of service policy. The results of this study are superficial, further research is needed to find out the reasons individually with a qualitative approach.

\section{CONFLICT OF INTEREST}

The authors state that there is no conflict of interest for this article.

\section{REFERENCES}

Brydsten, A., Hammarström, A. and San Sebastian, M. (2018) 'Health inequalities between employed and unemployed in northern Sweden: A decomposition analysis of social determinants for mental health', International Journal for Equity in Health, 17(1). doi: 10.1186/s12939018-0773-5.

Carrillo, J. E. et al. (2011) 'Defining and targeting health care access barriers.', Journal of health care for the poor and underserved, 22(2), pp. 562-575. doi: 10.1353/hpu.2011.0037.

Chiapella, L. C., Menna, J. M. and Mamprin, M. E. (2018) 'Potentially Inappropriate Medications in
Elderly Ambulatory Patients: A Comparative Study between a Primary Health Care Center and a Community Pharmacy', Value in Health Regional Issues, 17, pp. 119-125. doi: 10.1016/j.vhri.2017.12.009.

Chuah, F. L. H. et al. (2018) 'The health needs and access barriers among refugees and asylumseekers in Malaysia: A qualitative study', International Journal for Equity in Health, 17(120), pp. 1-15. doi: 10.1186/s12939-0180833-x.

Dehbarez, N. T. et al. (2018) 'Does free choice of hospital conflict with equity of access to highly specialized hospitals? A case study from the Danish health care system', Health Policy, 122(7). doi: 10.1016/j.healthpol.2018.04.006.

Dhruve, S., Badgaiyan, Y. D. and Pandey, S. (2016) 'A Study of Socio Economic Factors Affecting Family Planning Services in An Urban Area', International Journal of Scientific Research, 5(6), pp. 618-620.

East Java Central Bureau (2019) Persentase Penduduk Lansia Hasil Proyeksi Penduduk Menurut Kabupaten/Kota di Jawa Timur, 20102020, East Java Central Bureau. Available at: https://jatim.bps.go.id/dynamictable/2018/02/06 /328/persentase-penduduk-lansia-hasil-

proyeksi-penduduk-menurut-kabupaten-kotadi-jawa-timur-2010-2020.html (Accessed: 20 February 2019).

East Java Provincial Health Office (2018) Rencana Kerja Dinas Kesehatan Provinsi Jawa Timur Tahun 2018. Available at: https://erenggar.kemkes.go.id/file2018/eperformance/2-059010-2tahunan-623.pdf.

El-Sayed, A. M., Vail, D. and Kruk, M. E. (2018) 'Ineffective insurance in lower and middle income countries is an obstacle to universal health coverage', Journal of global health, 8(2), pp. 1-10. doi: 10.7189/jogh.08.020402.

$\mathrm{Fu}, \mathrm{X}$. et al. (2018) 'Influencing factors of inequity in health services utilization among the elderly in China 14 Economics 1402 Applied Economics 11 Medical and Health Sciences 1117 Public Health and Health Services', International Journal for Equity in Health, 17(1). doi: 10.1186/s12939-018-0861-6.

González, M. J. (2005) 'Access to mental health services: The struggle of poverty affected urban children of color', Child and Adolescent Social Work Journal, 22(3-4), pp. 245-256. doi: 10.1007/s10560-005-0036-3.

Hahn, R. ., Truman, B. . and Williams, D. . (2018) 'Civil rights as determinants of public health and racial and ethnic health equity: Health care, education, employment, and housing in the United States', SSM - Population Health, 4, pp. 17-24. doi: 10.1016/j.ssmph.2017.10.006.

Hamzah, O. S. and Tamba, L. (2018) 'Determinants of Implementation of Bureaucracy Behavior in Health Service in Community Health Center', Indian Journal of Public Health Research \& 
Development, 9(3), pp. 292-296. doi: 10.5958/0976-5506.2018.00225.5.

Holliday, T. L. et al. (2017) 'Disparities in rural breast cancer care: Factors affecting choice of breast reconstruction in a West Virginia Tertiary Care Hospital', American Surgeon, 83(7), pp. 717721.

Johar, M. et al. (2018) 'Inequality in access to health care, health insurance and the role of supply factors', Social Science and Medicine, 213, pp. 134-145. doi: 10.1016/j.socscimed.2018.07.044

Karuaihe, S. T. and Wandschneider, P. R. (2018) 'Limited access to services for the urban poor in Windhoek, Namibia', Development Southern Africa, 35(4), pp. 466-479. doi: 10.1080/0376835X.2018.1475219.

Kusumawardani, N. et al. (2018) 'Socio-economic, demographic and geographic correlates of cigarette smoking among Indonesian adolescents: results from the 2013 Indonesian Basic Health Research (RISKESDAS) survey', Global Health Action, 11, pp. 54-62. doi: 10.1080/16549716.2018.1467605.

Laksono, A. D., Nantabah, Z. K. and Wulandari, R. D. (2018) 'Access Barriers to Health Center for Elderly in Indonesia', Buletin Penelitian Sistem Kesehatan, 21(4), pp. 228-235. doi: 10.22435/hsr.v2li4.887.

Laksono, A. D. and Rachmawaty, T. (2013) 'Akseptabilitas Bidan terhadap Implementasi Kebijakan Jaminan Persalinan di Kabupaten Mojokerto', Buletin Penelitian Sistem Kesehatan, 16(4), pp. 341-349.

Langley, E. L., Wootton, B. M. and Grieve, R. (2018) 'The Utility of the Health Belief Model Variables in Predicting Help-Seeking Intention for Anxiety Disorders', Australian Psychologist, 53, pp. 291-301. doi: 10.1111/ap.12334.

Lee, Y.-H. et al. (2018) 'Growing concerns and controversies to Taiwan's National Health Insurance-what are the lessons from mainland China, South Korea and Singapore?', International Journal of Health Planning and Management, 33(1), pp. e357-e366. doi: 10.1002/hpm.2387.

Li, C., Yao, N. (Aaron) and Aitian Yin (2018) 'Disparities in dental healthcare utilization in China', Community Dentistry and Oral Epidemiology, 46(6), pp. 576-585. doi: 10.1111/cdoe.12394.

$\mathrm{Li}$, J. et al. (2018) 'Urban-rural disparities in health care utilization among Chinese adults from 1993 to 2011', BMC health services research, 18(102), pp. 1-9. doi: 10.1186/s12913-018-2905-4.

Lungu, E. A. et al. (2018) 'What influences where they seek care? Caregivers' preferences for underfive child healthcare services in urban slums of Malawi: A discrete choice experiment', PLoS ONE, $\quad$ 13(1).

doi: 10.1371/journal.pone.0189940.

Megatsari, H. et al. (2018) 'Community Perspective about Health Services Access', Buletin
Doi: 10.20473/jaki.v7i2.2019.147-154

Penelitian Sistem Kesehatan, 21(4), pp. 247253. doi: $10.22435 / h s r . v 2 l i 4.231$

Mubasyiroh, R., Nurhotimah, E. and Laksono, A. D. (2016) 'Indeks Aksesibilitas Pelayanan Kesehatan di Indonesia', in Supriyanto, S., Chalidyanto, D., and Wulandari, R. D. (eds) Aksesibilitas Pelayanan Kesehatan di Indonesia. Jogjakarta: PT Kanisius, pp. 21-58.

National Institute of Health Research and Development (2013) Riset Kesehatan Dasar 2013. Jakarta: Ministry of Health of the Republic of Indonesia.

Pratiwi, N. L. et al. (2014) 'Kajian Kebijakan Penyaluran Dana Bantuan Operasional Kesehatan dalam Mendukung Pencapaian Kesehatan Ibu dan Anak (MDG's 4,5) di Tiga Kabupaten, Kota di Provinsi Jawa Timur Indonesia', Buletin Penelitian Sistem Kesehatan, 17(4), pp. 395405.

Putri, Y. S. E. and Riasmini, N. M. (2013) 'The Predictors of Caregiver's Burden and Depression Level in Caring Elderly People with Dementia at Community', Jurnal Ners, 8(1), pp. 88-97. doi: 10.20473/jn.v8i1.3882.

Rinaldi, G., Kiadaliri, A. A. and Haghparast-Bidgoli, H. (2018) 'Cost effectiveness of HIV and sexual reproductive health interventions targeting sex workers: A systematic review', Cost Effectiveness and Resource Allocation, 16(63). doi: 10.1186/s12962-018-0165-0.

Sari Rochman, E. M. et al. (2018) 'Method Extreme Learning Machine for Forecasting Number of Patients' Visits in Dental Poli (A Case Study: Community Health Centers Kamal Madura Indonesia)', Journal of Physics: Conference Series, $\quad 953 . \quad$ doi: $\quad 10.1088 / 1742-$ 6596/953/1/012133.

Song, I. G., Shin, S. H. and Kim, H.-S. (2018) 'Improved regional disparities in neonatal care by government-led policies in Korea', Journal of Korean Medical Science, 33(6). doi: 10.3346/jkms.2018.33.e43.

Song, Y. et al. (2018) 'Spatial and temporal variations of spatial population accessibility to public hospitals: a case study of rural-urban comparison', GIScience and Remote Sensing, 55(5), pp. 718-744. doi: 10.1080/15481603.2018.1446713.

Suharmiati, Laksono, A. D. and Astuti, W. D. (2013) 'Policy Review on Health Services in Primary Health Center in the Border and Remote Area', Buletin Penelitian Sistem Kesehatan, 16(2), pp. $109-116$

Tebay, V. (2018) 'The strategy in improving quality of health services for patient satisfaction in community health clinic (Puskesmas) North Jayapura, Jayapura City', Indian Journal of Public Health Research and Development, 9(4), pp. 189-193. doi: 10.5958/09765506.2018.00281.4

Telleen, S. et al. (2012) 'Access to oral health services for urban low-income Latino children: Social ecological influences', Journal of Public Health 
Dentistry, 72(1), pp. 8-18. doi: 10.1111/j.17527325.2011.00275.x.

Wong, R. C. P. and Szeto, W. Y. (2018) 'An alternative methodology for evaluating the service quality of urban taxis', Transport Policy, 69, pp. 132-140. doi: 10.1016/j.tranpol.2018.05.016.

World Health Organization (2018) Vulnerable groups, Environmental health in emergencies. Available at: http://www.who.int/environmental_health_emer gencies/vulnerable_groups/en/ (Āccessed: 10 July 2018).

Wulandari, R. D. et al. (2019) 'Socioeconomic Disparities in Hospital Utilization among Elderly People in Indonesia', Researchgate. doi: 10.13140/RG.2.2.11898.54721.

$\mathrm{Xu}, \mathrm{Y}$. et al. (2018) 'Catastrophic health expenditure in households with chronic disease patients: A pre-post comparison of the New Health Care Reform in Shaanxi Province, China', PLOS ONE. Edited by U. Simeoni, 13(3), pp. 1-13. doi: 10.1371/journal.pone.0194539.

Yildiz, M. S., Heboyan, V. and Khan, M. M. (2018) 'Estimating technical efficiency of Turkish hospitals: Implications for hospital reform initiatives', BMC Health Services Research, 18(401), pp. 1-16. doi: 10.1186/s12913-0183239-y.

Yu, T.-H., Matthes, N. and Wei, C.-J. (2018) 'Can urban-rural patterns of hospital selection be changed using a report card program? A nationwide observational study', International Journal of Environmental Research and Public Health, 15(9), pp. 1-12. doi: 10.3390/ijerph15091827.

Yuan, Y. et al. (2018) 'Socioeconomic and Geographic Disparities in Accessing Nursing Homes With High Star Ratings', Journal of the American Medical Directors Association, 19(10), pp. 1-8. doi: 10.1016/j.jamda.2018.05.017. 